\title{
PREVENTION OF CELL SWELLING WITH LOW CHLORIDE ST. THOMAS' HOSPITAL SOLUTION IMPROVES POSTISCHEMIC MYOCARDIAL RECOVERY
}

A. Mark Jayawant, $\mathrm{MD}^{\mathrm{a}}$

Edward R. Stephenson, Jr., ${ }^{\text {a }} \mathrm{MD}$

Clive M. Baumgarten, $\mathrm{PhD}^{\mathrm{b}}$

Ralph J. Damiano, Jr., MD
Objective: In isolated myocytes cardioplegia-induced cell swelling can be prevented by lowering the $\mathrm{KCl}$ product by replacing $\mathrm{Cl}^{-}$with an impermeant ion. This study tested the hypothesis that $\mathrm{Cl}^{-}$substitution in St. Thomas' Hospital cardioplegic solution would result in superior myocardial protection in the intact, blood-perfused heart. Methods: Using a parabiotic, isolated rabbit heart Langendorff model, hearts were exposed to 1 hour of hypothermic $\left(10^{\circ}\right.$ to $\left.12^{\circ} \mathrm{C}\right)$, global ischemia followed by 30 minutes of reperfusion. Isosmotic cardioplegia was administered as a single $50 \mathrm{ml}$ bolus of either standard St. Thomas' Hospital solution $\left(\left[\mathrm{K}^{+}\right]_{0} \times\right.$ $\left.\left[\mathrm{Cl}^{-}\right]_{\mathrm{o}}=2566.4(\mathrm{mmol} / \mathrm{L})^{2}\right)$ or low $\mathrm{Cl}^{-}$St. Thomas' Hospital solution $\left(\left[\mathrm{K}^{+}\right]_{\mathrm{o}} \times\left[\mathrm{Cl}^{-}\right]_{\mathrm{o}}=700(\mathrm{mmol} / \mathrm{L})^{2}\right)$. Chloride was replaced by a large, impermeant ion, methanesulfonate. Postreperfusion systolic function and atrioventricular conduction times were measured before ischemia and after reperfusion. Results: Hearts receiving low $\mathrm{Cl}^{-}$St. Thomas' Hospital cardioplegia demonstrated significantly better postischemic functional recovery (74\% $\pm 3 \%$ ) compared with those treated with standard high $\mathrm{Cl}^{-} \mathrm{St}$. Thomas' Hospital solution $(55 \% \pm 4 \%, p=0.003)$. In addition, atrioventricular conduction times remained normal in the low $\mathrm{Cl}^{-}$group but were significantly prolonged in the St. Thomas' Hospital group. Conclusions: Lowering the $\mathrm{KCl}$ product of St. Thomas' Hospital solution makes it isotonic with plasma and prevents cellular edema. This ameliorates the detrimental functional and electrophysiologic sequelae of hypothermic, hyperkalemic cardioplegia. (J Thorac Cardiovasc Surg 1998;115:1196-202)
Prev revious attempts to prevent myocardial edema have focused on the osmolarity of the cardioplegic solutions and the use of membrane stabilizing agents. ${ }^{1-4}$ However, a solution may be isosmotic with plasma and still induce cell swelling if it is hypotonic. Although osmolarity is an intrinsic property of the

From the Department of Surgery, Division of Cardiothoracic Surgery, The Milton S. Hershey Medical Center, Pennsylvania State University, Hershey, Pa., ${ }^{\mathrm{a}}$ and the Department of Physiology, Medical College of Virginia, Virginia Commonwealth University, Richmond, $\mathrm{Va}{ }^{\mathrm{b}}$

Supported by National Institutes of Health grants HL-51032 (R.J.D.), HL-09310 (A.M.J., R.J.D.), and HL-46764 (C.M.B.).

Received for publication April 25, 1997; revisions requested Sept. 15, 1997; revisions received Dec. 10, 1997; accepted for publication Dec. 22, 1997.

Address for reprints: Ralph J. Damiano, Jr., MD, Chief, Division of Cardiothoracic Surgery, The Milton S. Hershey Medical Center, Penn State Geisinger Health System, P.O. Box 850, Hershey, PA 17033.

Copyright (C) 1998 by Mosby, Inc.

$0022-5223 / 98 \$ 5.00+0 \quad \mathbf{1 2 / 1 / 8 8 6 9 0}$ solution, tonicity depends on the properties of both the solution and the cell membrane, and membrane properties are highly sensitive to temperature. ${ }^{5} \mathrm{Re}$ cent studies on isolated rabbit and human myocytes suggest that edema may be a direct consequence of the tonicity of isosmotic cardioplegic solutions. ${ }^{6,7}$ Lowering the $\mathrm{KCl}$ product by partially replacing $\left[\mathrm{Cl}^{-}\right]_{\mathrm{o}}$ with a large, impermeant ion made St. Thomas' Hospital solution isotonic and prevented cell swelling during the period of exposure. ${ }^{6}$ However, extrapolation of data from single myocytes to the intact heart must be done cautiously. The single cell model fails to incorporate the myriad interactions between myocytes and neural, vascular, and interstitial elements, and the complex geometry of the intact heart., 7 Therefore this study was designed to test the hypothesis that the prevention of cellular swelling by changing the tonicity of the cardioplegic solution would ameliorate the detrimental contractile and electrophysiologic sequelae of hypothermic, hyperkalemic cardioplegia in the more clinically relevant intact heart. 


\section{Methods}

Adult New Zealand White rabbits of either sex, weighing 2.8 to $3.1 \mathrm{~kg}$, were used in this study. All animals received humane care in American Association for the Accreditation of Laboratory Animal Care-approved, United States Department of Agriculture-registered facilities in compliance with the "Principles of Laboratory Animal Care" formulated by the National Society for Medical Research and the "Guide for the Care and Use of Laboratory Animals" prepared by the Institute of Laboratory Animal Resources and published by the National Institutes of Health (NIH Publication No. 86-23, revised 1985.) Experiments were designed to compare the effect of standard and low $\mathrm{Cl}^{-}$St. Thomas' Hospital cardioplegic solution on postischemic function of hearts mounted and perfused on a parabiotic Langendorff apparatus.

\section{Experimental preparation}

Preparation of the support animal. The support animal was anesthetized by intramuscular administration of acepromazine maleate (INN: acepromazine) $(1 \mathrm{mg} / \mathrm{kg})$ and xylazine $(17.5 \mathrm{mg} / \mathrm{kg})$ followed by ketamine $(62.5$ $\mathrm{mg} / \mathrm{kg}$ ). A tracheostomy was performed, and mechanical ventilation was initiated (model 683, Harvard Apparatus, Dover, Mass.). Ventilator settings were adjusted to maintain arterial $\mathrm{pH}$ between 7.35 and 7.5 , carbon dioxide tension $\left(\mathrm{PCO}_{2}\right)$ between 35 and $45 \mathrm{~mm} \mathrm{Hg}$, and oxygen tension $\left(\mathrm{PO}_{2}\right)$ more than $200 \mathrm{~mm} \mathrm{Hg}$.

Heparin $(2500 \mathrm{U})$ was given through an ear vein. The right femoral artery was cannulated, the cannula connected to a pressure transducer (model P231D, Gould Inc., Cleveland, Ohio), and blood pressure was continuously displayed. Systolic blood pressure was maintained greater than $80 \mathrm{~mm} \mathrm{Hg}$ by transfusion of either blood collected from the donor animal or electrolyte solution (Plasma-Lyte, Baxter Healthcare Corp., Deerfield, Ill.), and serial hematocrits were measured.

The left internal jugular vein and carotid artery were cannulated to provide extracorporeal circulation, and arterial blood was delivered to perfuse a modified Langendorff apparatus as described previously. ${ }^{8}$ Column effluent was returned to the support animal.

Preparation of the donor animal and isolated heart. The donor animal was also prepared as described above. A rapid cardiectomy was accomplished through a median sternotomy, and blood for transfusion was collected from the thoracic cavity. The aorta was rapidly cannulated, the heart suspended from a modified Langendorff apparatus, and blood perfusion begun.

To monitor contractile function, a fluid-filled latex balloon was placed into the left ventricle and secured with a purse-string suture in the mitral valve anulus. The balloon was connected by way of polyethylene tubing to a pressure transducer (model P231D, Gould, Cleveland, Ohio). The zero pressure reference was set at the level of the aortic valve.

Two needle electrodes were secured in the right atrial appendage and connected to a pacemaker (model 5320, Medtronic, Inc., Minneapolis, Minn.). The heart was paced at a constant rate throughout the study. Two additional electrodes were placed on the left ventricular epicardium to monitor a bipolar electrogram. The electrodes were connected to a preamplifier and amplifier (model 11-G5407-58 and 13-4615-58, Gould Inc.) and band pass filtered between 0.05 and $1000 \mathrm{~Hz}$. The pressure and electrogram waveforms were displayed continuously and digitized at $1000 \mathrm{~Hz}$ with a WINDAQ/200 system (DATAQ Instruments, Akron, Ohio). Coronary flow was measured by an in-line flow probe and continuously monitored with a flowmeter (model T206, Transonic Systems, Inc., Ithaca, N.Y.).

The heart was enclosed in a water-jacketed beaker, and myocardial temperature was monitored with a probe placed in the right ventricle (model BAT 8, Bailey Instruments, Saddle Brook, N.J.). Hearts were warmed and cooled by switching flow between a $37^{\circ} \mathrm{C}$ water bath (model D1, Haake Co., Berlin, Germany) and a $10^{\circ} \mathrm{C}$ water bath (model 9010, Fisher Scientific, Pittsburgh, Pa.) connected in parallel to the water-jacketed beaker. Blood perfusate was maintained at $37^{\circ} \mathrm{C}$ by a separate water bath (model D1, Haake Co., Berlin, Germany). At hourly intervals, heparin (500 U) was administered to the support animal.

Experimental protocol. After instrumentation, hearts were given 30 minutes to equilibrate, and baseline data were acquired. Hearts that did not generate a systolic pressure exceeding $80 \mathrm{~mm} \mathrm{Hg}$ at an end-diastolic pressure (EDP) of $10 \mathrm{~mm} \mathrm{Hg}$ were excluded from the study. Intracavitary left ventricular pressure waveforms and left ventricular bipolar electrograms were recorded at seven fixed left-ventricular end-diastolic pressures (LVEDP) $(0$, $2.5,5,10,15,20$, and $25 \mathrm{~mm} \mathrm{Hg}$ ) attained by adjusting balloon volume. Then balloon volume was reduced to produce a $5 \mathrm{~mm} \mathrm{Hg} \mathrm{LVEDP.}$

Hearts were randomized to undergo a single $50 \mathrm{ml}$ infusion of one of two cold cardioplegic solutions $\left(10^{\circ} \mathrm{C}\right)$ at the onset of 60 minutes of global ischemia $\left(10^{\circ}\right.$ to $\left.12^{\circ} \mathrm{C}\right)$. Either standard St. Thomas' Hospital solution $\left(\left[\mathrm{K}^{+}\right]_{\mathrm{o}} \times\left[\mathrm{Cl}^{-}\right]_{\mathrm{o}}=2566.4[\mathrm{mmol} / \mathrm{L}]^{2}\right.$, Plegisol, Abbott Laboratories, North Chicago, Ill.), or a modified, low $\mathrm{Cl}^{-}$ St. Thomas' Hospital solution was administered. ${ }^{6}$

Low $\mathrm{Cl}^{-}$St. Thomas' Hospital solution $\left(\left[\mathrm{Cl}^{-}\right]_{\mathrm{o}}=43.75\right.$ $\mathrm{mmol} / \mathrm{L}$ ) was made by substituting an equimolar amount of Na-methanesulfonate for all $\mathrm{NaCl}$ and $\mathrm{K}$-methanesulfonate for part of the $\mathrm{KCl}$ in St. Thomas' Hospital solution so that the product $\left[\mathrm{K}^{+}\right]_{\mathrm{o}} \times\left[\mathrm{Cl}^{-}\right]_{\mathrm{o}}$ was $700(\mathrm{mmol} / \mathrm{L})^{2}$. This low $\mathrm{Cl}^{-}$cardioplegic solution is isotonic and did not affect the volume of isolated myocytes. ${ }^{6}$ Methanesulfonate was chosen as the substitute for $\mathrm{Cl}^{-}$because it is a large impermeant anion that does not chelate $\mathrm{Ca}^{2+}$. Furthermore, its $\mathrm{pK}_{\mathrm{a}}$ of approximately 1.2 is sufficiently low that negligible amounts of the permeant protonated species are present at physiologic $\mathrm{pH}^{6}{ }^{6}$ The osmolarities of the standard and low $\mathrm{Cl}^{-}$solutions were not significantly different (243 \pm 5 and $237 \pm 6$ mOsm, respectively).

To examine whether methanesulfonate itself had a cardioprotective effect, another large impermeant anion, aspartate, was used to lower the $\left[\mathrm{K}^{+}\right]\left[\mathrm{Cl}^{-}\right]$product. Aspartate also has a low pKa. In this group $(n=6)$, equimolar amounts of Na-aspartate was substituted for all the $\mathrm{NaCl}$ and $\mathrm{K}$-aspartate for some of the $\mathrm{KCl}$ in St. Thomas' Hospital solution. This also lowered the $\left[\mathrm{K}^{+}\right]\left[\mathrm{Cl}^{-}\right]$product to $700(\mathrm{mmol} / \mathrm{L})^{2}$.

After 1 hour of global ischemia, hearts were rewarmed and reperfused for 30 minutes. Intracavitary left ventric- 


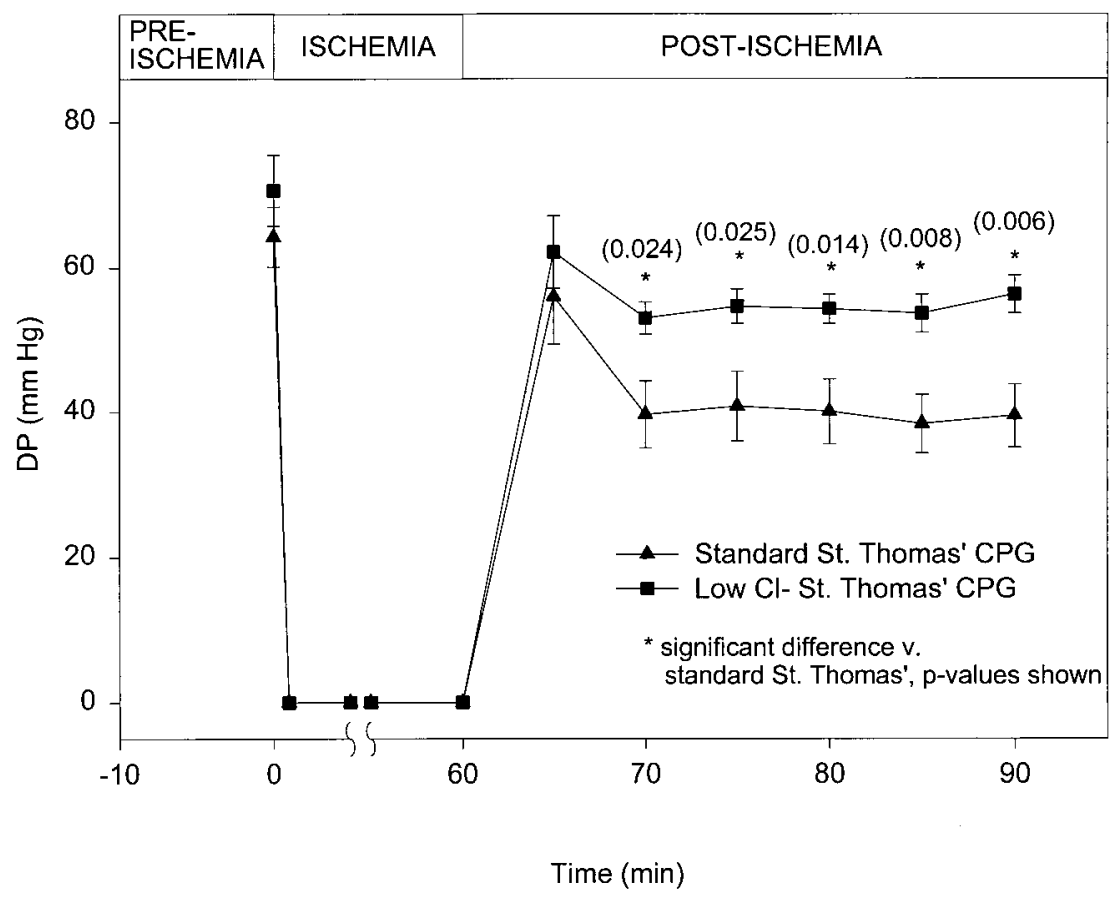

Fig. 1. Developed pressure $(D P)$ under preischemic conditions (time $=0$ minutes) and effect of standard and low $\mathrm{Cl}^{-}$St. Thomas' Hospital solution on DP during the reperfusion period (time $=60$ to 90 minutes). Values are expressed as mean \pm standard error of the mean. *Significant difference versus St. Thomas' Hospital solution, with $p$ values shown in parentheses.

Coronary flow. Both groups exhibited a significant increase in coronary flow immediately on reperfusion (Fig. 2). Reperfusion hyperemia lasted longer in the low $\mathrm{Cl}^{-} \mathrm{St}$. Thomas' Hospital group. At 5 minutes, the flow in the standard cardioplegia group had returned to preischemic levels, whereas coronary blood flow was still significantly elevated in the low $\mathrm{Cl}^{-}$group.

Myocardial tissue water. Mean percent tissue water for standard and low $\mathrm{Cl}^{-}$St. Thomas' Hospital cardioplegia was $78.0 \% \pm 0.4 \%$ and $78.6 \% \pm 0.2 \%$, respectively. There were no statistically significant differences between the two groups.

Atrioventricular conduction times. The P-R interval was significantly prolonged throughout the reperfusion period compared with baseline in the standard St. Thomas' Hospital group (Fig. 3). In contrast, no conduction delay was observed in the low $\mathrm{Cl}^{-}$St. Thomas' Hospital group.

Alternative anion. An alternative anion, aspartate, was examined to investigate whether there was any protective effect of methanesulfonate itself. Both of the low $\mathrm{Cl}^{-}$solutions had identical $\left[\mathrm{K}^{+}\right]\left[\mathrm{Cl}^{-}\right]$ products. The low $\mathrm{Cl}^{-} \mathrm{St}$. Thomas' Hospital solution formulated with aspartate had an identical protective effect when compared with the methanesulfonate group. There was a $69 \% \pm 2 \%$ recovery of DP in this group. This was significantly better than standard St. Thomas' Hospital solution $(p<0.05)$ and not significantly different than the methanesulfonate group. Similar to the methanesulfonate group, there also was no significant prolongation of the P-R interval in the aspartate hearts, $119 \pm 5 \mathrm{msec}$ before versus $110 \pm 9 \mathrm{msec}$ after ischemia $(p=0.62)$.

\section{Discussion}

Under hypothermic conditions, the activity of the transporters and pumps that normally regulate cell volume are markedly depressed, which leaves only passive fluxes of ions to modulate cell volume..$^{6,7,11}$ Because of the high membrane permeabilities to $\mathrm{K}^{+}$ and $\mathrm{Cl}^{-}$, the $\mathrm{KCl}$ product inside the cell must equal the $\mathrm{KCl}$ product outside the cell under these conditions. ${ }^{5}$ This would predict that cell swelling would occur with exposure to St. Thomas' Hospital solution because St. Thomas' Hospital solution has a much greater $\mathrm{KCl}$ product $\left(2566.4[\mathrm{mmol} / \mathrm{L}]^{2}\right)$ than either blood plasma (350 to $550[\mathrm{mmol} / \mathrm{L}]^{2}$ ) or 


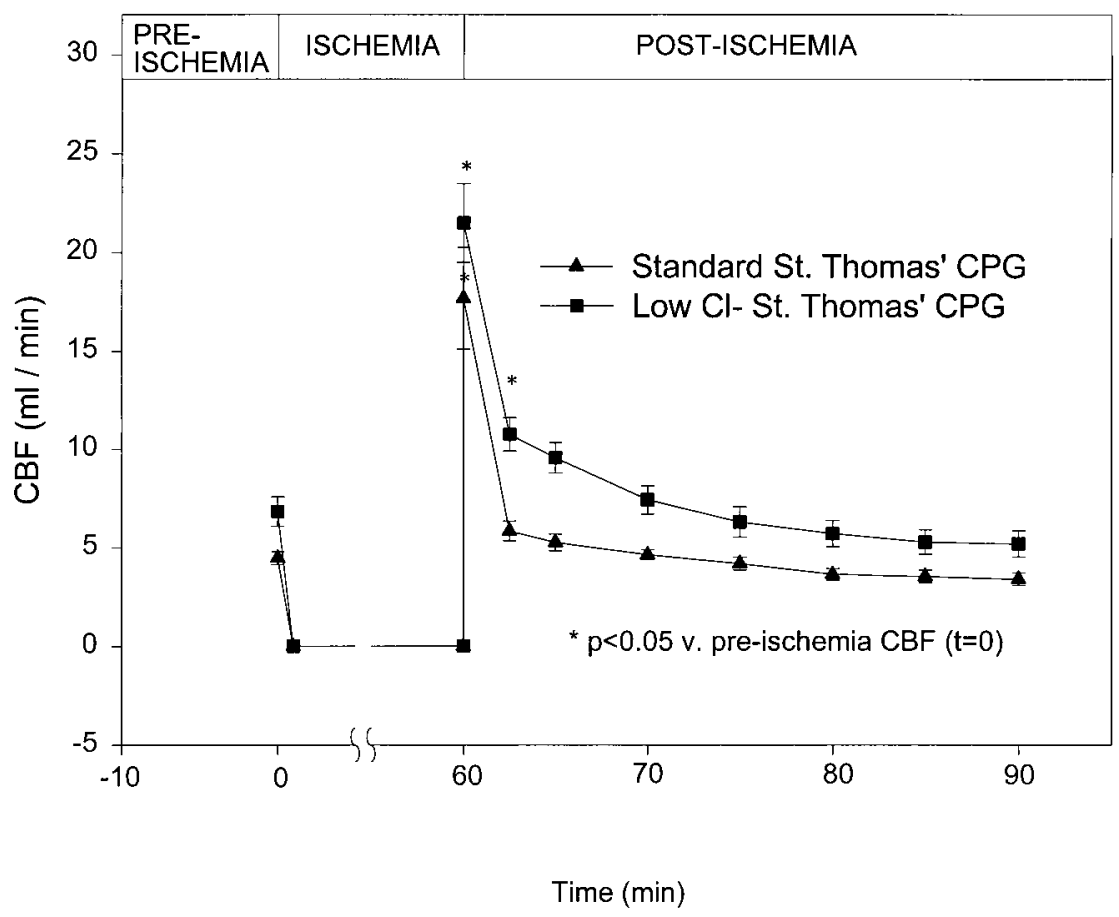

Fig. 2. Coronary blood flow $(C B F)$ under preischemic conditions (time $=0$ minutes) and effect of standard and low $\mathrm{Cl}^{-}$St. Thomas' Hospital solution on $\mathrm{CBF}$ during the reperfusion period (time $=60$ to 90 minutes). Values are expressed as mean \pm standard error of the mean. ${ }^{*} p<0.05$ versus respective preischemic level.

physiologic crystalloid (e.g., Tyrode's solution, 700 $\left.[\mathrm{mmol} / \mathrm{L}]^{2}\right)$. By lowering the $\mathrm{KCl}$ product of cardioplegic solution while maintaining osmolarity constant by partially replacing $\left[\mathrm{Cl}^{-}\right]_{\mathrm{o}}$ with a large, impermeant ion, cell swelling was prevented in isolated myocytes. ${ }^{6}$ This study was designed to examine whether lowering the $\mathrm{KCl}$ product would improve myocardial protection in an intact, bloodperfused heart.

Functional consequences of low $\mathrm{Cl}^{-}$hyperkalemic cardioplegia. Lowering the $\mathrm{KCl}$ product significantly improved postischemic recovery of DP, ameliorating myocardial stunning. This is consistent with the fact that intracellular edema has been shown to result in ultrastructural disturbances such as mitochondrial swelling and vacuolization of the sarcoplasm. ${ }^{12}$ Moreover, derangements in intracellular volume may adversely influence the regulation of cellular metabolism, hormone, and transmitter release. ${ }^{12-14}$ Further studies will be needed to address the specific mechanisms involved in this injury.

An alternate explanation for our results is that the $\mathrm{Cl}^{-}$ion possesses some inherent toxicity. However, this ubiquitous ion has not been shown in any previous study to be toxic within its physiologic range of concentrations. Another explanation for our findings would be that methanesulfonate itself possessed inherent cardioprotective effects. However, we obtained identical results with an alternate impermeant anion, aspartate. These data strongly suggest that it is the correction of the hypotonicity of the cardioplegic solution that is critical, not the specific impermeant anion used to achieve this result.

Low $\mathrm{Cl}^{-}$St. Thomas' Hospital solution did not offer better preservation of LV diastolic compliance (Table I). This is not surprising. In isolated myocyte preparations, cell swelling returned to baseline within 20 minutes of reperfusion. ${ }^{6}$ In this study, percent tissue water in the standard St. Thomas' Hospital group was not significantly different from that of the low $\mathrm{Cl}^{-}$St. Thomas' Hospital group after 30 minutes of reperfusion. Thus one would not have expected a change in ventricular compliance at that point.

Coronary blood flow. Myocardial edema has been associated with decreased coronary perfusion. ${ }^{15,16}$ In the standard St. Thomas' Hospital 


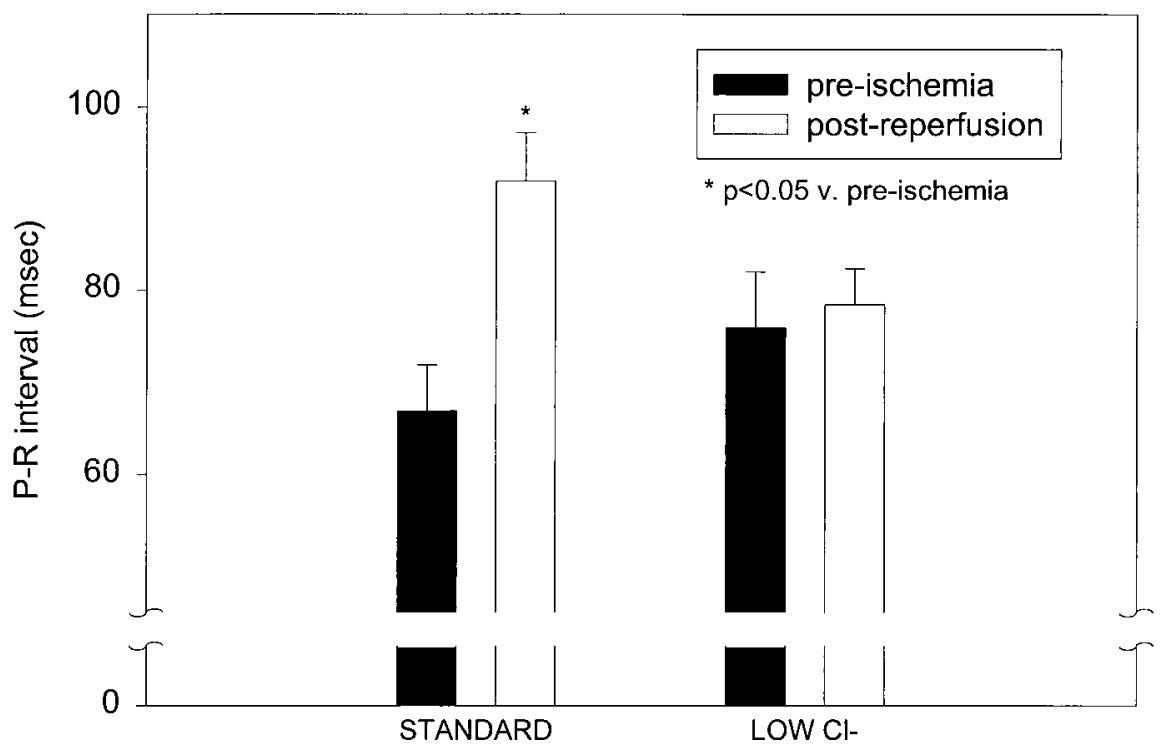

Fig. 3. Effect of standard and low $\mathrm{Cl}^{-}$St. Thomas' Hospital solution on atrioventricular conduction times after reperfusion. Values are expressed as mean \pm standard error of the mean. $\mathrm{LOW} \mathrm{Cl}$, $\mathrm{Low} \mathrm{Cl}^{-} \mathrm{St}$. Thomas' Hospital solution; STANDARD, Standard St. Thomas' Hospital solution. ${ }^{*} p<0.05$ versus preischemic P-R interval.

group an initial reperfusion hyperemia dropped to preischemic values almost immediately. In the low $\mathrm{Cl}^{-}$cardioplegia group reperfusion flow remained elevated for 5 minutes (Fig. 2). One explanation for this is that myocardial, or perhaps vascular, edema early in the reperfusion period blunted the hyperemic response in the standard St. Thomas' Hospital group compared with the low $\mathrm{Cl}^{-}$group. As edema resolved over the reperfusion period, coronary flow returned to normal levels. Alternatively, whole-cell patch-clamp studies of isolated rabbit coronary artery smooth muscle cells have characterized a chloride current that contributes to coronary vasoconstriction. ${ }^{17}$ It is possible that coronary smooth muscle activation was transiently affected by the low $\mathrm{Cl}^{-}$milieu.

Atrioventricular conduction. Our laboratory and others have shown that cell swelling and edema are associated with slowed ventricular conduction..$^{9,18}$ In this study, the conduction delay observed after standard cardioplegia (Fig. 3) was not seen in the low $\mathrm{Cl}^{-}$cardioplegia group. In previous work, we have hypothesized that the conduction delays associated with hyperkalemic solutions were due to an increase in cell volume, which decreased the extracellular space, resulting in a higher resistance to current flow. ${ }^{18,19}$ This hypothesis is supported by our observations in isolated myocytes ${ }^{6}$ and by this study. Because slowed conduction velocity plays a central role in arrhythmogenesis, ${ }^{20,21}$ the postoperative arrhythmias common after cardiac procedures may be prevented by reformulating standard cardioplegic solutions.

Advantages and disadvantages of the blood-perfused isolated heart Langendorff model. The advantages and drawbacks of this model have been previously described. ${ }^{8}$ The more physiologic nature of this model is a distinct advantage over nonparabiotic and crystalloid-perfused models. However, although this model offers a closer approximation to the clinical scenario, care should be taken in extrapolating results from in vitro studies to the clinical setting.

\section{Conclusion}

These results demonstrate a clear correlation between the prevention of cell swelling and the amelioration of the detrimental contractile and electrophysiologic sequelae of hypothermic, hyperkalemic cardioplegia. Blood-perfused isolated hearts treated with low $\mathrm{Cl}^{-}$, St. Thomas' Hospital cardioplegic solution displayed significantly improved postischemic functional recovery and shorter atrioventricular conduction times when compared with standard high $\mathrm{Cl}^{-}$St. Thomas' Hospital solution. New strategies aimed at correcting the hypotonicity 
of cardioplegic solutions and preventing cell swelling may improve myocardial protection with hyperkalemic cardioplegia.

\section{REFERENCES}

1. Foglia RP, Steed DL, Follette DM, DeLand E, Buckberg GD. Iatrogenic myocardial edema with potassium cardioplegia. J Thorac Cardiovasc Surg 1979;78:217-22.

2. Goto R, Tearle H, Steward DJ, Ashmore PG. Myocardial edema and ventricular function after cardioplegia with added mannitol. Can J Anesth 1991;38:7-14.

3. Niaz Z, Flodin P, Joyce L, et al. Effects of glucocorticoids in patients undergoing coronary artery bypass surgery. Chest 1979;76:262-8.

4. Hu D, Weng Z, Nicolosi AC, et al. Quantitative effects of myocardial edema on the left ventricular pressure-volume relation. J Thorac Cardiovasc Surg 1993;106:651-7.

5. Baumgarten CM, Feher JJ. Osmosis and the regulation of cell volume. In: Sperelakis N, editor. Cell physiology source book. New York: Academic Press; 1995. p. 180-211.

6. Drewnowska K, Clemo HF, Baumgarten CM. Prevention of myocardial intracellular edema induced by St. Thomas' Hospital cardioplegic solution. J Mol Cell Cardiol 1991;23:1215-21.

7. Shaffer RF, Baumgarten CM, Damiano RJ Jr. Prevention of cellular edema directly caused by hypothermic cardioplegia: studies in isolated human and rabbit atrial myocytes. J Thorac Cardiovasc Surg 1998;115:1189-95.

8. Maskal SL, Cohen NM, Hsia PW, Wechsler AW, Damiano RJ. Hyperpolarized cardiac arrest with a potassium-channel opener, aprikalim. J Thorac Cardiovasc Surg 1995;110:108395.

9. Kleber AG, Oetliker H. Cellular aspects of early contractile failure in ischemia. In: Fozzard GA, Have E, Jennings RB, Katz AM, Morgan HE, editors. The heart and cardiovascular system. New York: Raven Press; 1992. p. 1875-973.

10. Lawton J, Sepic J, Allen C, Hsia P, Damiano R. Myocardial protection with potassium channel openers is as effective as St. Thomas' solution in the rabbit heart. Ann Thorac Surg 1996;62:31-9.
11. Drewnowska K, Baumgarten CM. Regulation of cellular volume in rabbit ventricular myocytes: bumetanide, chlorothiazide and ouabain. Am J Physiol 1991;260:C12231.6.

12. Jennings RB, Schaper J, Hill ML, Steenbergen C, Reimer KA. Effect of reperfusion late in the phase of reversible ischemic injury, changes in cell volume, electrolytes, metabolites, and ultrastructure. Circ Res 1985;56:262-78.

13. Lang F, Buisch GL, Bolkl H, Haussinger D. Cell volume: a second message in regulation of cellular function. NIPS 1995;10:18-22.

14. Reimer KA, Jennings RB. Myocardial ischemia, hypoxia and infarction. In: Fozzard HA, Haber E, Jennings RB, Katz AM, Morgan HE, editors. The heart and cardiovascular system. 2nd ed. New York: Raven Press; 1992. p. 1875-973.

15. Frame LH, Powell WJ. Progressive resistance to coronary blood flow in the low flow ischemic state. Circulation 1975; 52(Suppl):II183.

16. Willerson JT, Watson JT, Hutton I, Templeton GH, Fixler DE. Reduced myocardial reflow and increased coronary vascular resistance following prolonged myocardial ischemia in the dog. Circ Res 1975;36:771-81.

17. Lamb FS, Volk KA, Shibata EF. Calcium-activated chloride current in rabbit coronary artery myocytes. Circ Res 1994;75: $742-50$.

18. Cohen NM, Allen CA, Belz MK, Nixon TE, Wise RM, Damiano RJ. Electrophysiological consequences of hypothermic hyperkalemic elective cardiac arrest. J Card Surg 1993;8:156-60.

19. Cohen NM, Allen CA, Hsia P, Nixon TE, Wise RM, Damiano RJ. Electrophysiological consequences of hyperkalemic cardioplegia during surgical ischemia. Ann Thorac Surg 1994;57:1076-83.

20. Boineau JP, Cox JL. Slow ventricular activation in acute myocardial infarction: a source of reentrant premature ventricular contractions. Circulation 1973;43:702-16.

21. Josephson ME, Seides SF. Ventricular tachycardia. In: Clinical cardiac electrophysiology, techniques and interpretations. Philadelphia: Lea \& Febiger; 1979. p. 247-80. 